\title{
NOTES
}

\section{BETTER NEVER THAN LATE: PRE-ARREST DELAY AS A VIOLATION OF DUE PROCESS}

Pre-arrest delay occurs when there is a time lapse between completion of a prosecution's investigation of a case and notification of the defendant of the charges to be brought against him. ${ }^{1}$ In Ross v. United States, ${ }^{2}$ the Court of Appeals for the District of Columbia, relying upon its supervisory power over criminal proceedings, ${ }^{3}$ became the first court to reverse a criminal conviction on the basis of prejudicial prearrest delay. The court in dictum also stated that pre-arrest delay might violate the due process clause of the fifth amendment. ${ }^{4}$

Other courts, both state and federal, have responded to Ross by treating pre-arrest delay claims as constitutional violations, ${ }^{5}$ and dicta in two subsequent United States Supreme Court opinions acknowledge the possibility of a fifth amendment violation resulting from pre-indictment delay. ${ }^{6}$ The constitutional standard suggested by the Supreme Court is very strict, ${ }^{7}$ and the lower courts have applied it in conflicting ways. ${ }^{8}$ The concept of deciding pre-arrest delay cases under the court's supervisory powers has been in essence disregarded, with the result that many defendants who might have received reversals under an equity-supervisory evaluation lost their appeals because they were unable to meet the applicable constitutional standards. ${ }^{9}$

This Note will review the factors considered by the courts in evaluating pre-arrest delay claims and will analyze how these factors have been organized into different standards for passing upon such claims. The Note will further suggest a two-pronged analysis of pre-arrest delay claims: first, as a claim under the constitutional right to due process

1. See Note, Pre-Arrest Delay: Evolving Due-Process Standards, 43 N.Y.U. L. Rev. 722,728 (1968)

2. 349 F.2d 210 (D.C. Cir. 1965).

3. For a discussion of supervisory powers, see notes 19-20 infra and accompanying text.

4. $349 \mathrm{~F} .2 \mathrm{~d}$ at 211 . See text accompanying note 16 infra.

5. See cases cited at notes 17-18 infra.

6. United States v. Lovasco, 431 U.S. 783, $796-97$ (1977); United States v. Marion, 404 U.S. 307, 324-25 (1971).

7. See text accompanying note 25 infra.

8. See text accompanying notes $28-33$ infra.

9. See text accompanying notes 18-21 infra. 
of law in criminal proceedings and, second, as an appeal to a court to apply its equitable supervisory powers to prevent gross and substantial injustice.

\section{Historical BACKGROUND}

In the landmark case of Ross $v$. United States, ${ }^{10}$ the Court of Appeals for the District of Columbia reversed a criminal conviction because of a lengthy and unjustified pre-arrest delay. The defendant, a man of limited education and irregular employment, was arrested -seven months after allegedly selling narcotics to an undercover policeman. He testified that he was unable to reconstruct the events of the day of the offense, and even the policeman was unable to testify without refreshing his memory by reference to a notebook. The court found that there had been a "purposeful delay" by the police ${ }^{11}$ and that the delay was not "necessitated by the requirements of effective lawenforcement" since the undercover narcotics investigation conducted during the three months prior to the arrest involved primarily duplication of previous investigations. ${ }^{12}$

The court also found that the defendant had asserted a "plausible claim of inability to recall or reconstruct the events of the day of the offense,"13 and pointed out that the prosecution was based solely upon the refreshed recollection of one witness. ${ }^{14}$ In light of these factors, the circuit court reversed the conviction, relying upon its "supervisory responsibility for criminal proceedings." 15 In addition to its holding, the court recognized the principle that "due process may be denied when a formal charge is delayed for an unreasonably oppressive and unjustifiable time after the offense to the prejudice of the accused." 16

The immediate judicial response to Ross was ambiguous at best. ${ }^{17}$

10. 349 F.2d 210 (D.C. Cir. 1965).

11. Id. at 215 .

12. Id. at 213 .

13. Id. at 215.

14. Id. at $211,215$.

15. Id at 216.

16. Id. at 211 (quoting Nickens v. United States, 323 F.2d 808,810 n.2 (D.C. Cir. 1963)).

17. The Sixth Circuit rejected the Ross principle, Lothridge v. United States, 441 F.2d 919 (6th Cir.), cert. denied, 404 U.S. 1003 (1971), while the Fifth Circuit refused to take any position, McConnell v. United States, 402 F.2d 852 (5th Cir.), cert. denied, 394 U.S. 933 (1969). The application of the Ross principle made some progress in the federal district courts, however, as six indictments were dismissed and/or convictions overturned between 1968 and 1971. United States v. Kleinbard, 333 F. Supp. 699 (E.D. Pa. 1971); United States v. Jones, 322 F. Supp. 1110 (E.D. Pa. 1971); United States v. King, 332 F. Supp. 1072 (E.D. Wis. 1971); United States v. Wahrer, 319 F. Supp. 585 (D. Alas. 1970); United States v. Haulman, 288 F. Supp. 775 (E.D. Mich. 1968); United States v. Curry, 284 F. Supp. 458 (N.D. Ill. 1968). In the state courts, the Ross principle was cautiously applied, as only two state courts reversed on Ross grounds prior to 1971. People 
Furthermore, those courts that accepted the Ross principle defined it in terms of a due process violation rather than as a matter of their supervisory jurisdiction. ${ }^{18}$ Although the federal courts and most of the state courts have the power to reverse convictions on the sole basis of gross or substantial injustice, independent of any specific legal point of appeal, ${ }^{19}$ and although this power has often been exercised, ${ }^{20}$ the courts chose to develop a new constitutional doctrine. In employing this doctrine, however, courts frequently distinguished cases on their facts, and

v. Hryciuk, 36 Ill. 2d 500, 224 N.E.2d 250 (1967); People v. Hernandez, 15 Mich. App. 141, 170 N.W.2d 851 (1969).

18. See, e.g., United States v. Feldman, 425 F.2d 688 (3d Cir. 1970); United States v. Baker, 424 F.2d 968 (4th Cir. 1970); Acree v. United States, 418 F.2d 427 (10th Cir. 1969); Jordan v. United States, 416 F.2d 338 (9th Cir. 1969), cert. denied, 397 U.S. 920 (1970); United States v. Lee, 413 F.2d 910 (7th Cir. 1969), cert. denied, 396 U.S. 1022 (1970); United States v. Feinberg, 383 F.2d 60 (2d Cir. 1967); Schlinsky v. United States, 379 F.2d 735 (1st Cir. 1967), cert. denied, 389 U.S. 920 (1968); Terlikowski v. United States, 379 F.2d 501 (8th Cir.), cert. denied, 389 U.S. 1008 (1967); McKay v. State, 489 P.2d 145 (Alas. 1971); State v. Hodge, 153 Conn. 564, 219 A.2d 367 (1966); People v. Hryciuk, 36 Ill. 2d 500, 224 N.E.2d 250 (1967); Jones v. State, 3 Md. App. 616, 240 A.2d 790 (1968); Commonwealth v. Jones, 360 Mass. 498, 275 N.E.2d 143 (1971); People v. Hernandez, 15 Mich. App. 141, 170 N.W.2d 851 (1969); State v. Deckard, 459 S.W.2d 342 (Mo. 1970); Scott v. State, 84 Nev. 530, 444 P.2d 902 (1968); State v. Roundtree, 106 N.J. Super. 135, 254 A.2d 337 (1969), rev'd on other grounds, 118 N.J. Super. 22, 285 A.2d 564 (1971); State v. Baca, 82 N.M. 144, 477 P.2d 320 (Ct. App. 1970); People v. Collins, 66 Misc. 2d 340, 320 N.Y.S.2d 693 (1971); State v. McClintick, 23 Ohio Misc. 194, 255 N.E.2d 885 (1970); Commonwealth v. McCloud, 218 Pa. Super. Ct. 230, 275 A.2d 841 (1971); Gonzales v. State, 47 Wis. 2d 548, 177 N.W.2d 843 (1970). But see United States v. Sanchez, 361 F.2d 824 (2d Cir. 1966), in which the court noted that Ross was decided pursuant to the D.C. Circuit's supervisory responsibilities over its criminal proceedings.

19. The Supreme Court has discussed the federal courts' supervisory powers as follows:

Judicial supervision of the administration of criminal justice in the federal courts implies the duty of establishing and maintaining civilized standards of procedure and evidence. Such standards are not satisfied merely by observance of those minimal historic safeguards for securing trial by reason which are summarized as "due process of law" and below which we reach what is really trial by force.

McNabb v. United States, 318 U.S. 332, 340 (1943).

State courts have long claimed similar powers to direct the course of criminal trials and to set standards of fairness higher than those required by constitutional mandates. E.g., Hohl v. Board of Educ., 250 Iowa 502, 94 N.W.2d 787 (1959); Bender v. Eaton, 343 S.W.2d 799 (Ky. 1961); In re Mild's Estate, 25 N.J. 467, 136 A.2d 875 (1957); State ex rel. Anaya v. Scarborough, 75 N.M. 702, 410 P.2d 732 (1966); State ex rel. Olson v. Lynch, 138 N.W.2d 785 (N.D. 1965); Staub v. Tehol Corp., 205 Pa. Super. Ct. 606, 211 A.2d 88 (1965); State ex rel. Reynolds v. County Ct., 11 Wis. 2d 560, 105 N.W.2d 876 (1960). But see Winfrey v. Chandler, 159 Tex. 220, 318 S.W.2d 59 (1958).

20. See, e.g., Thiel v. Southern Pacific Co., 328 U.S. 217 (1945) (Court exercised supervisory powers to reverse conviction where daily wage earners were excluded from jury panel); McNabb v. United States, 318 U.S. 332 (1943) (Court exercised supervisory powers to suppress confession obtained in an uncivilized manner); United States v. Toscanino, 500 F.2d 267 (2d Cir. 1974) (court exercised supervisory powers to refuse jurisdiction over Frisbee v. Collins-type defendants (Frisbee v. Collins, 342 U.S. 179 (1952)); Burton v. United States, 483 F.2d 1182 (9th Cir. 1973) (court exercised supervisory powers to assure strict compliance with rule 11); United States v. Fioravanti, 412 F.2d 407 (3d Cir.), cert. denied, 396 U.S. 837 (1969) (court exercised supervisory powers to declare that the use of Allen charges will normally result in reversal). 
convictions were rarely overturned. ${ }^{21}$

The United States Supreme Court finally addressed the issue in United States $v$. Marion, ${ }^{22}$ a case involving a three-year pre-indictment delay. The indictment against the defendant had been dismissed by the United States District Court for the District of Columbia. ${ }^{23}$ The Supreme Court reversed this dismissal, finding that the defendant's claim of prejudice was purely speculative and holding the statute of limitations to be the primary guarantee against overly stale criminal charges. $^{24}$ The Court qualified its decision, however, and for the first time recognized that undue pre-arrest or pre-indictment delay may violate due process:

Nevertheless, . . . since appellees may claim actual prejudice to their defense, it is appropriate to note here that the statute of limitations does not fully define the appellees' rights with respect to the events occurring prior to indictment. Thus, the Government concedes that the Due Process Clause of the Fifth Amendment would require dismissal of the indictment if it were shown at trial that the pre-indictment delay in this case caused substantial prejudice to appellees' rights to a fair trial and that the delay was an intentional device to gain tactical advantage over the accused. ...25

The Court further observed that almost any delay, no matter how reasonable, may harm the defendant's case ${ }^{26}$ and that a showing of prejudice without more would not necessarily violate due process. ${ }^{27}$ Thus, the Marion dictum clearly acknowledged that a due process claim might result from pre-arrest delay and seemingly identified two factors - substantial prejudice to the defendant's right to a fair trial and use of the delay as an intentional device to gain tactical advantage over the accused - that must exist concurrently in order to establish a constitutional violation. Nevertheless, the lower courts have maintained that Marion failed to state conclusively whether the two factors cited were

21. See cases cited at note 18 supra.

22. 404 U.S. 307 (1971).

23. Id at 310 .

24. Id at 322,326 . The Court dismissed the defendant's claim based on the sixth amendment, holding that the right to a speedy trial attaches only after formal charges have been brought. Id. at 320.

25. Id. at 324 (footnote omitted). Furthermore, the Court's opinion seemed to authorize the lower court to reconsider its dismissal after trial: "Events of the trial may demonstrate actual prejudice, but at the present time appellees' due process claims are speculative and premature." Id at 326. However, the Court has since stated that this passage "establishes only that proof of actual prejudice makes a due process claim concrete and ripe for adjudication, not that it makes the claim automatically valid." United States v. Lovasco, 431 U.S. 783, 789 (1977).

26. 404 U.S. at 324.

27. Id. at 324-25; accord, United States v. Lovasco, 431 U.S. 783, 790 (1977) ("proof of prejudice is generally a necessary but not sufficient element of a due process claim"). See text accompanying note 41 infra. 
to be applied in a conjunctive or disjunctive fashion. ${ }^{28}$ The result has been a split among the circuits and the states, with some courts applying the factors disjunctively, ${ }^{29}$ some conjunctively, ${ }^{30}$ some adopting a balancing test, ${ }^{31}$ some refusing to take a definitive position ${ }^{32}$ and others rejecting the Ross-Marion principle altogether. ${ }^{33}$

The proper constitutional treatment of the pre-arrest delay problem was most recently faced by the Supreme Court in United States $v$. Lovasco ${ }^{34}$ which involved an eighteen-month delay in indicting a defendant for possession of firearms stolen from the mail and for dealing in firearms without a license. ${ }^{35}$ The defendant claimed that as a result of the delay he had lost the testimony of two important witnesses, who had since died. No evidence concerning the reasons for the delay was offered by the government in the district court proceeding. In fact, the

28. E.g., United States v. Mays, 549 F.2d 670, 677 (9th Cir. 1977); United States v. Iannelli, 461 F.2d 483, 485 n.2 (2d Cir.), cert. denied, 409 U.S. 980 (1972). For a discussion of the application of Marion in the federal courts, see United States v. Alderman, 423 F. Supp. 847, $849-55$ (D. Md. 1976).

29. State v. Dietz, 289 N.C. 488,223 S.E.2d 357 (1976). See generally United States v. Giocalone, 477 F.2d 1273 (6th Cir. 1973); United States v. Stamas, 443 F.2d 860 (1st Cir.), cert. denied, 404 U.S. 851 (1971).

30. United States v. Cowsen, 530 F.2d 734 (7th Cir.), cert. denied, 426 U.S. 906 (1976); United States v. MacClain, 501 F.2d 1006 (10th Cir. 1974); Crawford v. State, 6 Ala. App. 71, 342 So. 2d 450 (1977); State v. Wilbanks, 95 Idaho 346, 509 P.2d 331 (1973); State v. Royal, 217 Kan. 197, 535 P.2d 413 (1975); Blake v. State, 15 Md. App. 674, 292 A.2d 780 (1972); State v. Thomas, 529 S.W.2d 379 (Mo. 1975).

31. This test essentially involves weighing the reasonableness of the delay against the prejudice suffered by the defendant, but does not require that the defendant prove a deliberate attempt by the prosecution to gain a tactical advantage. United States v. Mays, 549 F.2d 670 (9th Cir. 1977); United States v. Jackson, 504 F.2d 337 (8th Cir. 1974), cert. denied, 420 U.S. 964 (1975); United States v. Benson, 487 F.2d 978 (3d Cir. 1973); United States v. Iannelli, 461 F.2d 483 (2d Cir.), cert. denied, 409 U.S. 980 (1972); Marks v. State, 496 P.2d 66 (Alas. 1972); People v. Vanderburg, 32 Cal. App. 3d 526, 108 Cal. Rptr. 104 (1973); Coca v. District Ct., 187 Colo. 280, 530 P.2d 958 (1975); In re G.T., 304 A.2d 865 (D.C. 1973); State v. Bryson, 53 Hawaii 652, 500 P.2d 1171 (1972); People v. Lawson, 67 Ill.2d 449, 367 N.E.2d 1244 (1977); People v. Fiorini, 53 Mich. App. 389, 220 N.W.2d 70 (1974), rev'd after rehearing on facts, 59 Mich. App. 243, 229 N.W.2d 399 (1975); Commonwealth v. Barnes, 237 Pa. Super. Ct. 407, 352 A.2d 107 (1975).

32. McLawhorn v. North Carolina, 484 F.2d 1 (4th Cir. 1973); United States v. Judice, 457 F.2d 414 (5th Cir.), cert. denied, 409 U.S. 886 (1972). In more recent opinions, panels of the Fifth Circuit have opted for conflicting standards. Compare United States v. Shaw, 555 F.2d 1295 (5th Cir. 1977) (balancing test) with United States v. Rice, 550 F.2d 1364 (5th Cir. 1977) (disjunctive application) and United States v. Byrum, 540 F.2d 833 (5th Cir. 1976) (conjunctive application). Several states remain similarly uncommitted, see, e.g., Alexander v. State, 129 Ga. App. 395,199 S.E.2d 918 (1973); State v. Clapp, 335 A.2d 879 (Me. 1975); State v. Bellcourt, 293 Minn. 446, 196 N.W.2d 610 (1972), although it is clear from the opinions that in these jurisdictions the defendant has to establish that he has been prejudiced by the delay.

33. State v. Robles, 110 Ariz. 184, 516 P.2d 320 (1973); State v. Freeman, 276 So. $2 d 546$ (Fla. Dist. Ct. App.), cert. denied, 283 So. 2d 366 (1973); Baldwin v. State, 490 S.W.2d 583 (Tex. 1973).

34. 431 U.S. 783 (1977).

35. Id. at 784 . 
parties stipulated that little additional information related to the crimes was discovered subsequent to the preparation of a Postal Inspector's report one month after the commission of the crimes. ${ }^{36}$

The district court, finding that the delay of seventeen months after completion of the investigative report was "unnecessary and unreasonable" and that the defendant had been prejudiced as a result of the delay, dismissed the indictment. ${ }^{37}$ On appeal, the government for the first time offered an explanation for the delay, contending that further investigation had been necessary to establish that the defendant's son was responsible for the theft. ${ }^{38}$ Accepting the government's explanation on its face, the Eighth Circuit nevertheless found the delay to have been "unjustified, unnecessary, and unreasonable."39 The court also held that the defendant had demonstrated sufficient prejudice by asserting that one of the missing witnesses could have corroborated his contention that he was unaware that the guns were stolen. ${ }^{40}$

The Supreme Court began its analysis in Lovasco by noting that "Marion makes clear that proof of prejudice is generally a necessary but not sufficient element of a due process claim"41 and that "the due process inquiry must consider the reasons for the delay as well as the prejudice to the accused." 42 The Court then rejected the Eighth Circuit's conclusion that the government's hope of discovering other participants in the crimes was not adequate justification for the delay, cautioning that the "Due Process Clause does not permit courts to abort criminal prosecutions simply because they disagree with a prosecutor's judgment as to when to seek an indictment."43 Rather, a court's function is limited to determining whether pre-arrest delay in a given case offends "those fundamental conceptions of justice which lie at the base of our civil and political institutions." 44

Having framed the nature of its inquiry in this manner, the Court then observed that prosecutors are not constitutionally required to seek indictments as soon as probable cause exists to believe that a suspect has committed a crime, nor as soon as there is enough evidence to

36. Id

37. As reported in United States v. Lovasco, 532 F.2d 59, 60 (8th Cir. 1976), rev'd, 431 U.S. 783 (1977). The district court opinion is unpublished.

38. 431 U.S. at 786 .

39. 532 F.2d at 61 .

40. Id. The court, however, reversed the district court's dismissal of the count charging the defendant with dealing in firearms without a license, since it was not alleged that the missing witnesses could have helped to exculpate the defendant with respect to that charge.

41. 431 U.S. at 790 . See note 27 supra and accompanying text.

42. 431 U.S. at 790 .

43. $I d$.

44. Id. (quoting Mooney v. Holohan, 294 U.S. 103, 112 (1935)). 
prove guilt beyond a reasonable doubt. The Court noted that such a requirement would produce undesirable consequences for effective law enforcement ${ }^{45}$ and for the rights of the accused. ${ }^{46}$ Thus, a distinction was drawn between delay for investigative purposes and delay rooted solely in a desire to gain some advantage over the accused, "precisely because investigative delay is not so one-sided."47

Significantly, the Court in Lovasco did not even consider the nature or quantum of prejudice resulting to the defendant, holding instead that "to prosecute a defendant following investigative delay does not deprive him of due process, even if his defense might have been somewhat prejudiced by the lapse of time."48 Furthermore, although the trial record contained no evidence concerning the reasons for the delay, the Court accepted the government's appellate representations that the delay was caused by further investigative efforts, assuming them to "have been made in good faith." 49 The Court thus reversed the lower court's action and reinstated the indictment. ${ }^{50}$

As in Marion, however, the Court did leave open the possibility that pre-arrest delay could constitute a fifth amendment violation in other factual contexts:

45. According to the Court, "a requirement of immediate prosecution upon probable cause" could cause potential sources of information or evidence to disappear before proof of guilt beyond a reasonable doubt was amassed. 431 U.S. at 791-92. Such a requirement would also result in judicial resources being wasted on insubstantial matters and proceedings involving only some of the relevant parties or transactions.

Similarly, if prosecutors were compelled to file charges "as soon as the requisite proof has been developed against one participant on one charge," id. at 792-93, investigative efforts as to other suspects or other crimes might be hampered. Id. And, although additional charges might be brought subsequently in some cases, the result would be "multiple trials involving a single set of facts." Id. at 793. Prosecutors, in the face of such a rule, might also tend to resolve doubtful cases in favor of "early-and possibly unwarranted-prosecutions" in order to avoid the risk that a later indictment would be quashed on account of pre-arrest delay. Id. Finally, if prosecution were required to be initiated immediately upon obtaining evidence sufficient to establish guilt, the government would not be able to fully consider the desirability of proceeding in a particular case. Id. at 794.

46. The Court noted that any requirement that charges be brought upon the establishment of probable cause could "increase the likelihood of unwarranted charges being filed" and "add to the time during which defendants stand accused but untried." Id. at 791. And, as discussed in note 45 supra, the Court reasoned that such a rule might subject a defendant to multiple trials arising out of the same transactions.

As to a rule requiring indictments upon the obtaining of evidence sufficient to establish guilt, the Court pointed out that such a rule might lead to premature, unwarranted prosecutions and could possibly result in cases being tried that, upon fuller consideration, might not have been prosecuted. 431 U.S. at 790-92.

47. 431 U.S. at 795.

48. Id. at 796.

49. Id.

50. Id. at 797. 
In Marion we conceded that we could not determine in the abstract the circumstances in which preaccusation delay would require dismissing prosecutions. More than five years later, that statement remains true. Indeed, in the intervening years so few defendants have established that they were prejudiced by delay that neither this Court nor any lower court has had a sustained opportunity to consider the constitutional significance of various reasons for delay..$^{51}$ We therefore leave to the lower courts, in the first instance, the task of applying the settled principles of due process that we have discussed to the particular circumstances of individual cases. ${ }^{52}$

Inasmuch as the Lovasco decision failed to establish definitive standards according to which due process claims based upon pre-arrest delays should be evaluated, it can be assumed that the lower courts will continue to apply their own standards in the same conflicting manner in which they have been applied over the last twelve years. The next section of this Note will review the factors considered by the various lower federal and state courts in evaluating pre-arrest delay claims, and the following section will analyze how these factors have been organized into different standards for passing upon such claims.

\section{Factors Considered By the Courts}

\section{A. Prejudice.}

An essential element in a criminal defendant's assertion of a violation of due process caused by pre-arrest delay is a showing of prejudice to the preparation of his defense. When the delay is of short duration a few courts will presume a lack of prejudice. ${ }^{53}$ For administrative convenience, the District of Columbia Circuit has developed a rough rule of thumb-a lack of prejudice will be presumed from a delay of

51. This conclusion of the Court is questionable at best. In a number of lower court cases decided after Marion, the defendant was able to establish sufficient prejudice to warrant a consideration of the reason for the delay. E.g., United States v. Parish, 468 F.2d 1129 (D.C. Cir. 1972), cert. denied, 410 U.S. 957 (1973) (justification of diligent efforts to locate defendant outweighed prejudice); Robinson v. United States, 459 F.2d 847 (D.C. Cir. 1972) (justification of undercover narcotics investigation outweighed prejudice); United States v. Alderman, 423 F. Supp. 847 (D. Md. 1976) (evidence of intentional delay causing substantial prejudice to defendant required finding that prosecutorial delay had resulted in violation of defendant's due process rights); United States v. Kleinbard, 333 F. Supp. 699 (E.D. Pa. 1971) (prejudice to defendant outweighed reasons set forth by government as justification for delay). See also Marks v. State, 496 P.2d 66 (Alas. 1972) (delay of eight months prejudicial where state did not attempt to justify the delay); People v. Vanderburg, 32 Cal. App. 3d 526, 108 Cal. Rptr. 104 (1973) (remanded to determine if justification of continuing undercover narcotics investigation outweighed prejudice).

52. 431 U.S. at 796-97 (citations omitted).

53. United States v. Kellerman, 432 F.2d 371 (10th Cir. 1970) (two-week delay); Daniels v. United States, 357 F.2d 587 (D.C. Cir. 1966) (eight-week delay). 
less than four months. ${ }^{54}$ On the other hand, some courts will presume the existence of prejudice when the delay is unusually lengthy. ${ }^{55}$ In general, however, courts prefer not to presume the existence or lack of prejudice solely from the length of the delay. ${ }^{56}$

The major premise underlying an assertion of prejudice is that "an innocent man has no reason to fix in his memory the happenings on the day of the alleged crime," mentary evidence. Therefore, if a defendant has received any type of notice that he is under criminal suspicion before formal arrest, his claim of prejudice due to pre-arrest delay must fail..$^{58}$ Assuming, however, that a defendant has not received any pre-arrest notice of suspicion, the question arises as to what constitutes prejudice.

In Ross, a "plausible claim of inability to recall or reconstruct the

54. United States v. Jones, 524 F.2d 834 (D.C. Cir. 1975); Robinson v. United States, 459 F.2d 847 (D.C. Cir. 1972).

55. United States v. Jasper, 331 F. Supp. 814 (E.D. Pa. 1971), vacated and remanded for reconsideration, 460 F.2d 1224 (3d Cir. 1972) (two-and-one-third-year delay); People v. Hryciuk, 36 Ill. 2d 500, 224 N.E.2d 250 (1967) (fourteen-year delay); see King v. United States, 369 F.2d 213, 214 (D.C. Cir. 1966), cert. denied, 387 U.S. 910 (1967) (Edgerton, J., dissenting) (thirteenmonth delay). But see United States v. Tate, 336 F. Supp. 58 (E.D. Pa. 1971) (fifteen-month delay).

56. United States v. Stamas, 443 F.2d 860 (1st Cir.), cert. denied, 404 U.S. 851 (1971) (sixmonth delay will not be presumed unreasonable); United States v. Wilford, 364 F. Supp. 738 (D. Del. 1973), aff d, 493 F.2d 730 (3d Cir. 1974) (nine-week delay will not be presumed reasonable).

57. Nickens v. United States, 323 F.2d 808, 813 (D.C. Cir. 1963), cert. denied, 379 U.S. 905 (1964) (Wright, J., concurring).

58. See, e.g., United States v. McClure, 473 F.2d 81 (D.C. Cir. 1972) (defendant charged with embezzlement received notice that he was under criminal suspicion when he was fired from his job at credit union and sought the advice of counsel at that time); United States v. Feldman, 425 F.2d 688 (3d Cir. 1970) (defendant charged with concealing assets of a bankrupt from a receiver was put on notice that he was under criminal suspicion when he was interviewed by federal agents during the investigation); United States v. Milstein, 401 F.2d 51 (7th Cir. 1968) (defendant charged with possessing liquor bottles containing distilled spirits other than those originally bottled received notice that he was under criminal suspicion when his bottles were confiscated by law enforcement agents); Terlikowski v. United States, 379 F.2d 501 (8th Cir.), cert. denied, 389 U.S. 1008 (1967) (defendant facing federal charges for breaking into a U.S. post office received notice that he was under criminal suspicion when state charges growing out of the same incident were promptly filed against him and a preliminary hearing was held in municipal court); United States v. Kramer, 286 A.2d 856 (D.C. 1972) (defendant charged with negligent homicide received notice that he was under criminal suspicion when he was told, within one month of the offense, that charges would be brought against him); People v. Johnson, 41 Mich. App. 34, 199 N.W.2d 561 (1972) (defendant charged with assault with intent to do great bodily harm was presumed to have had notice that he was under criminal suspicion when he continually eluded police officers trying to apprehend him). It could even be argued that the defendant in Lovasco had notice that he was under criminal suspicion, as he "made numerous anxious inquiries of the postal inspectors concerning whether he would be indicted . . . ." United States v. Lovasco, 431 U.S. 783, 800 (1977) (Stevens, J., dissenting). If this is the case, then Lovasco's assertion of prejudice could have been immediately dismissed, and the Court should not have considered the factual question of when the investigation was complete. 
events of the day of the offense"59 was held to constitute prejudice. This seems to be a logical standard, because a truly "prejudiced" defendant would often be unable to state exactly how he had been prejudiced. ${ }^{60}$ A court exercising its supervisory powers could easily deem it inequitable to force such a defendant to stand trial. Even some courts that employ a constitutional analysis of pre-arrest delay claims have accepted the Ross "plausible claim of inability to remember" prejudice standard. ${ }^{61}$

A number of courts, however, faced with defendants who utilized a tactic of "selective nonremembrance," realized that a general claim of inability to recall could easily be feigned. ${ }^{62}$ The problem is mitigated somewhat in cases where the defendant receives a full trial and then appeals on the ground of pre-arrest delay, because the appellate court has the benefit of the trial record and can determine how much the defendant was in fact able to recall at trial. Courts have unanimously discounted a defendant's claim of prejudice in cases where he gave detailed testimony at trial ${ }^{63}$ or produced alibi witnesses. ${ }^{64}$ But the trial

59. Ross v. United States, 349 F.2d 210, 215 (D.C. Cir. 1965).

60. As the Ross court stated:

His failure of memory and his inability to reconstruct what he did not remember virtually precluded his showing in what respect his defense might have been more successful if the delay had been shorter . . . In a very real sense, the extent to which he was prejudiced by the Government's delay is evidenced by the difficulty he encountered in establishing with particularity the elements of that prejudice.

Id, cited in Dickey v. Florida, 398 U.S. 30, 54-55 (1969) (Brennan, J., concurring).

61. E.g., United States v. Lee, 413 F.2d 910 (7th Cir. 1969), cert. denied, 396 U.S. 1022 (1970); United States v. King, 332 F. Supp. 1072 (E.D. Wis. 1971); United States v. Wahrer, 319 F. Supp. 585 (D. Alas. 1970); United States v. Godfrey, 243 F. Supp. 830 (D.D.C. 1965), affd, 358 F.2d 850 (D.C. Cir. 1966); People v. Vanderburg, 32 Cal. App. 3d 526, 108 Cal. Rptr. 104 (1973); People v. Jennings, 11 Ill. App. 3d 940, 298 N.E.2d 409 (1973); People v. Hernandez, 15 Mich. App. 141, 170 N.W.2d 851 (1969).

62. Hurt v. United States, 314 A.2d 489, 494 (D.C. 1974); accord, United States v. Cowsen, 530 F.2d 734 (7th Cir.), cert. denied, 426 U.S. 906 (1976); United States v. Jackson, 504 F.2d 337 (8th Cir. 1974), cert. denied, 420 U.S. 964 (1975); McConnell v. United States, 402 F.2d 852 (5th Cir.), cert. denied, 394 U.S. 933 (1969) (court found that the defendant was "pig tracking" Ross and "setting up a situation to his advantage on claims which cannot be rebutted," 402 F.2d at 852-53); State v. Gardner, 534 S.W.2d 284 (Mo. Ct. App. 1976). But cf. State v. Roundtree, 106 N.J. Super. 135, 254 A.2d 337 (1969), aff'd in part and rev'd in part, 118 N.J. Super. 22, 285 A.2d 564 (1971) (trial court's finding that the defendant in fact had no recall held insufficient to establish prejudice).

63. E.g., United States v. Jones, 524 F.2d 834 (D.C. Cir. 1975); United States v. Jackson, 504 F.2d 337 (8th Cir. 1974), cert. denied, 420 U.S. 964 (1975); United States v. Lee, 413 F.2d 910 (7th Cir. 1969), cert. denied, 396 U.S. 1022 (1970); United States v. Capaldo, 402 F.2d 821 (2d Cir. 1968), cert. denied, 394 U.S. 989 (1969); United States v. Baillie, 316 F. Supp. 892 (D. Hawaii 1970); People v. Herrara, 539 P.2d 483 (Colo. App. 1975); State v. Clapp, 335 A.2d 897 (Me. 1975); People v. Johnson, 41 Mich. App. 34, 199 N.W.2d 561 (1972); State v. Polsky, 82 N.M. 393, 482 P.2d 257 (Ct. App. 1971), cert. denied, 404 U.S. 1015 (1972).

64. E.g., United States v. Jones, 524 F.2d 834 (D.C. Cir. 1975); Roy v. United States, 356 F.2d 785 (D.C. Cir. 1965); People v. Herrera, 539 P.2d 483 (Colo. App. 1975); State v. Hodge, 153 
courts that have had to pass upon pre-arrest delay claims at pre-trial hearings ${ }^{65}$ were still faced with the initial task of attempting to discern genuine cases of prejudice. Accordingly, the majority of courts have begun to demand a showing of prejudice greater than a general inability to recall or reconstruct events. ${ }^{66}$ This new standard of prejudice has been expressed in several different ways, ${ }^{67}$ but for the purpose of this Note, it will be referred to as "actual prejudice."

Under this standard, the most common ground for finding sufficient prejudice to warrant dismissal of an indictment or reversal of a conviction is the defendant's inability to produce specifically identified material witnesses. ${ }^{68}$ A few courts have recognized other factors, such as the disappearance or destruction of evidence, ${ }^{69}$ the unavailability of

Conn. 564, 219 A.2d 367 (1966); In re G.T., 304 A.2d 865 (D.C. 1973); People v. Johnson, 41 Mich. App. 34, 199 N.W.2d 561 (1972).

65. Indeed, a few courts have recommended that rulings on Ross-type motions be postponed until after the defendant has been tried so that a decision can be made in light of all of the evidence produced. The rationale behind this proposal is that a defendant facing trial has a much greater incentive to make diligent efforts to recall events and locate witnesses. People v. Lawson, 38 Ill. App. 3d 239, 347 N.E.2d 430 (1976), rev'd on other grounds, 67 Ill. 2d 449, 367 N.E.2d 1244 (1977); accord, United States v. Wilford, 364 F. Supp. 738 (D. Del. 1973), affd, 493 F.2d 730 (3d Cir. 1974); People v. Archerd, 3 Cal. 3d 615, 477 P.2d 421, 91 Cal. Rptr. 397 (1970); People v. Collins, 66 Misc. 2d 340, 320 N.Y.S.2d 693 (1971).

66. See cases cited at notes 67-71 infra.

67. See, e.g., United States v. Cowsen, 530 F.2d 734 (7th Cir.), cert. denied, 426 U.S. 906 (1976) ("actual prejudice"); United States v. Alred, 513 F.2d 330 (6th Cir.), cert. denied, 423 U.S. 828 (1975) ("substantial prejudice"); United States v. Golden, 436 F.2d 941, 943 (8th Cir.), cert. denied, 404 U.S. 910 (1971) ("peculiar circumstances" of prejudice); Marks v. State, 496 P.2d 66, 68 (Alas. 1972) ("fact of prejudice").

68. See, e.g., Woody v. United States, 370 F.2d 214 (D.C. Cir. 1966) (woman with whom defendant lived at time of offense died; another witness was himself arrested and refused to testify on fifth amendment grounds; conviction reversed); United States v. Alderman, 423 F. Supp. 847 (D. Md. 1976) (three defense witnesses denied recollection of events, and government's main witness could not recall crucial conversation; indictment dismissed); United States v. Kleinbard, 333 F. Supp. 699 (E.D. Pa. 1971) (defense was entrapment; witness who induced defendant to sell drugs was arrested and later committed to a mental health clinic; witness refused to testify on advice of attorney; indictment dismissed); United States v. Haulman, 288 F. Supp. 775 (E.D. Mich. 1968) (six defense witnesses died; indictment dismissed); United States v. Curry, 284 F. Supp. 458 (N.D. Ill. 1968) (defense was entrapment; informant could not be located; motion for judgment of acquittal sustained); United States v. Parrott, 248 F. Supp. 196 (D.D.C. 1965) (defense counsel filed list of prospective witnesses who were no longer available by reason of death or serious illness; indictment dismissed); Marks v. State, 496 P.2d 66 (Alas. 1972) (defense was unable to contact witnesses who had moved from the area; conviction reversed and indictment dismissed with prejudice); Commonwealth v. De Rose, 225 Pa. Super. Ct. 8, 307 A.2d 425 (1973) (three witnesses acknowledged by the Commonwealth could not be located, and the Commonwealth could not specify exact date of the offense; indictment dismissed); $c f$. People v. Archerd, 3 Cal. 3d 615, 477 P.2d 421, 91 Cal. Rptr. 397 (1970) (prosecution located the material witnesses requested by defendant; conviction affirmed).

69. United States v. Golden, 436 F.2d 941 (8th Cir.), cert. denied, 404 U.S. 910 (1971); United States v. Peterson, 302 F. Supp. 1232 (D. Minn. 1969). 
specific documents, ${ }^{70}$ or the state's inability to specify the exact date of the offense, ${ }^{71}$ as constituting sufficient "actual" prejudice.

The major import of this new standard is that, although the courts are no longer burdened with distinguishing between honest nonremembrance and a feigned lack of recall, the defendant's actual inability to reconstruct events is fatal to his fifth amendment claim. If he is unable to specify with particularity any missing witnesses or documents, then he is deemed not to have suffered sufficient prejudice. While the particularity requirement seems appropriate from a constitutional viewpoint in light of Marion and Lovasco, it ignores the notions of equity with which Ross was concerned. For example, a Ross-type defendant who honestly cannot recall the events of the day in question, and who may well be innocent, could never obtain relief under this standard, while the difficulty of establishing "actual prejudice" might not defeat the claim of a guilty defendant who may be more likely to remember the events of the day of the crime and can therefore show that a material witness is absent or that important evidence has been destroyed.

Furthermore, several courts have noted that a person's ability to account for his whereabouts and activities is often related to his social class. For example, the businessman who keeps desk calendars, appointment books and records of his daily transactions might find it easier to pinpoint alibi witnesses or material documents, and consequently their absence or destruction, than would a lower-class defendant who tends to "live from day to day." 72

Despite the inequities inherent in a standard demanding a high degree of particularity, a few courts employing a constitutional analysis have established a still higher standard of prejudice-some requiring the defendant to prove he made diligent attempts to locate the witness or document, ${ }^{73}$ and others requiring the defendant to prove that the

70. United States v. Bray, 442 F.2d 1064 (9th Cir. 1971).

71. Commonwealth v. De Rose, 225 Pa. Super. Ct. 8, 307 A.2d 425 (1973).

72. Powell v. United States, 352 F.2d 705, 711 (D.C. Cir. 1965) (Wright, J., dissenting). Compare Ross v. United States, 349 F.2d 210 (D.C. Cir. 1965), United States v. Jones, 322 F. Supp. 1110 (E.D. Pa. 1971) and People v. Hernandez, 15 Mich. App. 141, 170 N.W.2d 851 (1969) with United States v. Feinberg, 383 F.2d 60 (2d Cir. 1967) and Morrison v. United States, 365 F.2d 521 (D.C. Cir. 1966).

73. E.g., People v. Gilmore, 239 Cal. App. 2d 125, 48 Cal. Rptr. 449 (1965), cert. denied, 385 U.S. 961 (1966) (defendant who was given informer's name, description and address should have located and cross-examined informant before the latter left town; no prejudice); State v. Bryson, 53 Haw. 652, 500 P.2d 1171 (1972) (defendant did not make a good faith attempt to locate witnesses; no prejudice); People v. Lawson, 38 Ill. App. 3d 239, 347 N.E.2d 430 (1976), rev'd on other grounds, 67 Ill. 2d 449, 367 N.E.2d 1244 (1977) (defendant made diligent efforts to find out where he was on the day in question, but union of which he was a member was on strike, and fellow employees and friends could not remember, sufficient prejudice; indictment dismissed); People v. Iaconis, 31 Mich. App. 703, 188 N.W.2d 175 (1971) (defendant's witnesses could not remember 
missing evidence would have been materially helpful to his defense. ${ }^{74}$ Several courts have declared an absence of prejudice based on their own findings that the specifically identified missing evidence was not significant to the case. ${ }^{75}$ Although appropriate from a constitutional viewpoint, this standard lacks the flexibility necessary to treat fairly a Ross-type defendant that is available under the court's supervisory powers.

\section{B. Justification for the Delay.}

Since many courts have adopted a balancing approach to pre-arrest delay claims that weighs the prejudice to the defendant against the reasonableness of the delay ${ }^{76}$ there is substantial case law as to what constitutes a "justifiable" delay. ${ }^{77}$ Some pre-arrest delays are clearly justified, such as when the defendant's identity or complicity is unknown to the police, ${ }^{78}$ when the defendant is hiding from the police or

events; but defendant did not attempt to question those witnesses until nine months after his notice of alibi was filed; no prejudice); State v. Polsky, 82 N.M. 393, 482 P.2d 257 (1971), cert. denied, 404 U.S. 1015 (1972) (although college student's trial took place after his witnesses had left school, defendant was arrested five days before final exams; the witnesses were at another suspect's preliminary hearing that defendant's counsel also attended, so defendant could have arranged for witnesses to be present; no prejudice); State v. Hackett, 26 N.C. App. 239, 215 S.E.2d 832, cert. denied, 288 N.C. 246, 217 S.E.2d 670 (1975) (defendant made no discovery efforts to identify and locate the fifteen persons who were present at the scene of the crime; no prejudice).

74. State v. Dietz, 289 N.C. 488, 223 S.E.2d 357 (1976); see, e.g., United States v. Mays, 549 F.2d 670 (9th Cir. 1977) (defendant did not show what the testimony of the deceased witnesses would have been, nor did he show how the living witnesses would have testified had their memories not been dimmed; insufficient prejudice); United States v. Parish, 468 F.2d 1129 (D.C. Cir. 1972), cert. denied, 410 U.S. 957 (1973) (although the defendant's signature on a missing sign-in sheet may have shown that he was in class at the time of the offense, the court found that the order of names on the list might not necessarily correspond with arrival to class; no prejudice); Commonwealth v. Barnes, $237 \mathrm{~Pa}$. Super. Ct. 407, 352 A.2d 107 (1975) (only function of the missing informant as a witness would have been to shed light on the question of credibility; no specific prejudice shown from the loss of the original police records; insufficient prejudice).

75. United States v. Childs, 415 F.2d 535 (3d Cir. 1969) (court found that missing witnesses could not have materially aided defendant's case, in light of other evidence of culpability; no prejudice); United States v. Baillie, 316 F. Supp. 892 (D. Hawaii 1970) (court accepted agent's testimony that none of the defendant's missing alibi witnesses were present during the narcotics transaction; no prejudice); People v. Fiorini, 59 Mich. App. 243, 229 N.W.2d 399 (1975) (court found that testimony of two alibi witnesses was so unbelievable that testimony of deceased alibi witnesses would have been merely cumulative; no prejudice); State v. Polsky, 82 N.M. 393, 482 P.2d 257 (1971), cert. denied, 404 U.S. 1015 (1972) (court found that testimony of missing witnesses was not relevant to the narcotics transaction, but was only relevant to the credibility of the undercover agent; no prejudice); Commonwealth v. Barnes, $237 \mathrm{~Pa}$. Super. Ct. 407, 352 A.2d 107 (1975) (court found that the testimony of the missing informant would only have been relevant to the question of his credibility; insufficient prejudice).

76. See cases cited at note 31 supra.

77. See cases cited at note 51 supra.

78. See United States v. Bray, 442 F.2d 1064 (9th Cir. 1971) (principal did not implicate 
simply cannot be located, ${ }^{79}$ or when further investigation of other crimes of the defendant or his associates is necessary. ${ }^{80}$ However, a delay is clearly unjustified when, for instance, an indictment is deliberately delayed so that the fruits of discovery in a civil proceeding can be used in a subsequent criminal prosecution, ${ }^{81}$ where prosecution is belatedly commenced in retaliation for the defendant's victory on appeal from conviction of a separate offense ${ }^{82}$ or when an indictment is deliberately delayed in order to gain a tactical advantage over the defendant. $^{83}$

The validity of several other alleged justifications for pre-arrest delay is less clear. For example, in several cases the defendant has alleged that the delay, although not deliberate, was due to a lack of diligence. ${ }^{84}$ Such delays have, of course, been deemed justified where the courts have found that efforts to locate the defendant were diligent, albeit unsuccessful. ${ }^{85}$ However, when the courts have found a lack of diligence, the decisions have been inconsistent. ${ }^{86}$ Another unresolved

defendant until seven months after the offense); State v. Bellcourt, 293 Minn. 446, 196 N.W.2d 610 (1972) (police were unaware of defendant's identity).

79. "[O]ne cannot complain of a delay which he helped create." People v. Johnson, 41 Mich. App. 34, 43, 199 N.W.2d 561, 565 (1972) (defendant eluded officers trying to apprehend him); accord, United States v. Stanley, 422 F.2d 826 (9th Cir. 1969); United States v. Morris, 308 F. Supp. 1348 (E.D. Pa. 1970); People v. Iaconis, 31 Mich. App. 703, 188 N.W.2d 175 (1971); State v. Midell, 40 Wis. $2 d$ 516, 162 N.W.2d 54 (1968).

80. See, e.g., United States v. Lovasco, 431 U.S. 783 (1977) (investigation regarding defendant's accomplices); United States v. Iannelli, 461 F.2d 483 (2d Cir.), cert. denied, 409 U.S. 980 (1972) (investigation of defendants regarding other extortion activities); United States v. Stamas, 443 F.2d 860 (1st Cir.), cert. denied, 404 U.S. 851 (1971) (investigation of other suspected criminal activity on the part of defendant and his associates).

81. See United States v. Parrott, 248 F. Supp. 196 (D.D.C. 1965).

82. See People v. Hryciuk, 36 Ill. 2d 500, 224 N.E.2d 250 (1967).

83. See United States v. Marion, 404 U.S. 307 (1971).

84. See cases cited at notes $85-86$ infra.

85. United States v. Parish, 468 F.2d 1129 (D.C. Cir. 1972), cert. denied, 410 U.S. 957 (1973) (officers put a "stop" on defendant's criminal record, instigated a lookout via teletype, checked defendant's traffic records, visited defendant's parents' home, and checked with postal authorities for defendant's forwarding address); see United States v. Jones, 524 F.2d 834 (D.C. Cir. 1975); United States v. Childs, 415 F.2d 535 (3d Cir. 1969); King v. United States, 369 F.2d 213 (D.C. Cir. 1966), cert. denied, 387 U.S. 910 (1967); United States v. Pierce, 354 F. Supp. 616 (D.D.C. 1973), aff d, 498 F.2d 712 (D.C. Cir. 1974).

86. Several courts have ordered indictments dismissed for lack of diligence. United States v. Haulman, 288 F. Supp. 775 (E.D. Mich. 1968); United States v. Godfrey, 243 F. Supp. 830 (D.D.C. 1965), affd, 358 F.2d 850 (D.C. Cir. 1966); People v. Jennings, 11 Ill. App. 3d 940, 298 N.E.2d 409 (1973); People v. Fiorini, 53 Mich. App. 389, 220 N.W.2d 70 (1974), rev'd after rehearing on facts, 59 Mich. App. 243, 229 N.W.2d 399 (1975) (court on rehearing reversed dismissal of indictment due to finding of no prejudice). Other courts have held that the delays must be shown to have been purposeful. Crawford v. State, 6 Ala. App. 71, 342 So. 2d 450 (1977); Bond v. United States, 233 A.2d 506 (D.C. 1967); Commonwealth v. Jones, 360 Mass. 498, 275 N.E.2d 143 (1971). Two courts have remanded cases to the trial court in order to give the government a second chance to justify the delay or disprove the defendant's allegation of prejudice. United 
issue is whether delays due to administrative changes and shortages of manpower in the prosecutor's office should be deemed justifiable. ${ }^{87}$ The courts are also split as to whether delay is justified in order for the state to determine if a prosecution can be avoided. ${ }^{88}$

The most-litigated justification for pre-arrest delay has been an alleged need to continue undercover narcotics investigations. ${ }^{89}$ It is the usual practice of undercover narcotics agents, in order to maintain their "cover," to wait until they have completed a particular term of investigation before swearing out a complaint. ${ }^{90}$ Delay in the institution of a narcotics prosecution may also result from an effort to discover an offender's sources ${ }^{91}$ or otherwise to conduct a more complete investigation. ${ }^{92}$ Although the vast majority of courts considering the issue have determined delays rooted in such concerns to be legitimate, ${ }^{93}$ a few

States v. Mays, 549 F.2d 670 (9th Cir. 1977) (remanded for trial without prejudice to have trial court determine whether prejudice to defendant was sufficient to dismiss when delay was clearly due to negligence); Jones v. United States, 402 F.2d 639 (D.C. Cir. 1968).

87. Three courts have found this type of delay to be unjustifiable. United States v. Alderman, 423 F. Supp. 847,857 (D. Md. 1976) (if prosecution resources are scarce, the answer is to increase staff rather than shortchange due process rights); United States v. Haulman, 288 F. Supp. 775 (E.D. Mich. 1968) (personnel changes in the United States Attorney's Office did not justify delay); United States v. Curry, 284 F. Supp. 458 (N.D. Ill. 1968) (turnover of staff and pressure of work in prosecutor's office did not justify delay). However, two other courts have upheld such delays on the rationale that only purposeful delays are unjustifiable. United States v. Tate, $336 \mathrm{~F}$. Supp. 58 (E.D. Pa. 1971) (change of administration and severe shortages of manpower in United States Attorney's Office justified delay, where delay was not purposeful or oppressive); State v. Gardner, 534 S.W.2d 284 (Mo. Ct. App. 1976) (limited personnel and financial resources justified keeping narcotics agent undercover for an extended period of time, so long as delay was not to secure tactical advantage over defendant).

88. Compare United States v. Stewart, 426 F. Supp. 58 (E.D. Mich. 1976) (when defendant was involved in a first degree murder prosecution, state was justified in delaying indictment for armed bank robbery to see if prosecution could be avoided) with United States v. Jasper, $331 \mathrm{~F}$. Supp. 814 (E.D. Pa. 1971), vacated and remanded for reconsideration, $460 \mathrm{~F} .2 \mathrm{~d} 1224$ (3d Cir. 1972) (delay held unjustified when government was waiting to see whether "new developments" would obviate the need for an indictment).

89. See cases cited at notes $90-91,93-96$ infra.

90. See, e.g., United States v. Washington, 463 F.2d 904 (D.C. Cir. 1972); Wilson v. United States, 409 F.2d 184 (9th Cir.), cert. denied, 395 U.S. 983 (1969); People v. M., 61 Misc. 2d 542, 306 N.Y.S.2d 38 (County Ct. 1969); Commonwealth v. McCloud, 218 Pa. Super. Ct. 230, 275 A.2d 841 (1971).

91. See, e.g., United States v. Washington, 463 F.2d 904 (D.C. Cir. 1972); United States v. Kleinbard, 333 F. Supp. 699 (E.D. Pa. 1971).

92. See cases cited at note 93 infra.

93. E.g., United States v. Cowsen, 530 F.2d 734 (7th Cir.), cert. denied, 426 U.S. 906 (1976); United States v. Emory, 468 F.2d 1017 (8th Cir. 1972); Robinson v. United States, 459 F.2d 847 (D.C. Cir. 1972); Wilson v. United States, 409 F.2d 184 (9th Cir.), cert. denied, 395 U.S. 983 (1969); United States v. Williams, 352 F. Supp. 1387 (D.D.C. 1973); McKay v. State, 489 P.2d 145 (Alas. 1971); People v. Gilmore, 239 Cal. App. 2d 125, 48 Cal. Rptr. 449 (1965), cert. denied, 385 U.S. 961 (1966); State v. Hodge, 153 Conn. 564, 219 A.2d 367 (1966); State v. Royal, 217 Kan. 197, 535 P.2d 413 (1975); Jones v. State, 3 Md. App. 616, 240 A.2d 790 (1968); People v. Iaconis, 31 Mich. App. 703, 188 N.W.2d 175 (1971); State v. Gardner, 534 S.W.2d 284 (Mo. Ct. App. 1976); 
courts have insisted that such factors as the length and manner of conduct of the investigation be subjected to a reasonableness standard. ${ }^{94}$ And one court has held that a delay caused by an attempt to secure the defendant as an informer is improper and unjustified. ${ }^{95}$

Delays for the purpose of continuing an undercover narcotics investigation can be justified only so long as the investigation is in progress. Several courts have therefore dismissed indictments on the ground that once the agent had "broken cover," further delay was improper. $^{96}$

The question might be raised, however, whether any defendant who has truly demonstrated prejudice should be forced to stand trial, regardless of the government's justification. Even a valid reason for the delay does not help the accused remember his whereabouts on the day in question, nor does it revive a deceased witness for the purpose of providing testimony. Nevertheless, the Supreme Court has declared

State v. Roundtree, 106 N.J. Super. 135, 254 A.2d 337 (Middlesex County Ct.1969), rev'd on other grounds, 118 N.J. Super. 22, 285 A.2d 564 (App. Div. 1971); State v. Polsky, 82 N.M. 393,482 P.2d 257 (Ct. App. 1971), cert. denied, 404 U.S. 1015 (1972); State v. Baca, 82 N.M. 144, 477 P.2d 320 (Ct. App. 1970); People v. M., 61 Misc. 2d 542, 306 N.Y.S.2d 38 (County Ct. 1969); State v. Hackett, 26 N.C. App. 239, 215 S.E.2d 832, cert. denied, 288 N.C. 246, 217 S.E.2d 670 (1975); Commonwealth v. McCloud, 218 Pa. Super. Ct. 230, 275 A.2d 841 (1971); State v. Midell, 40 Wis. 2d 516, 162 N.W.2d 54 (1968).

94. See United States v. Jackson, 504 F.2d 337, 340 (8th Cir. 1974), cert. denied, 420 U.S. 964 (1975):

We agree that the appellant was not prejudiced, but we do feel it important to discuss the reasonableness of the delay. We are aware of the vital role played by informants and undercover agents in the apprehension of persons engaged in illegal drug traffic. Moreover, we respect the government's need to keep the identity of such informants and agents confidential, both to protect their safety and to continue to use them effectively. [Citations omitted.] However, when the government chooses to continue the use of a particular informant and delay the indictment of an individual already suspected of an offense, it must recognize and respect the suspect's "accelerating need to know that . . . he [is] ultimately going to be charged with having committed a [certain] crime at a certain time and place...."

Accord, United States v. Williams, 352 F. Supp. 1387 (D.D.C. 1973); People v. Lawson, 38 Ill. App. 3d 239, 347 N.E.2d 430 (1976), rev'd on other grounds, 67 Ill.2d 449, 367 N.E.2d 1244 (1977).

95. United States v. Curry, 284 F. Supp. 458 (N.D. Ill. 1968).

96. United States v. Kleinbard, 333 F. Supp. 699 (E.D. Pa. 1971) (first four-month delay was reasonable; next two-month delay was unjustified); United States v. Jones, 322 F. Supp. 1110 (E.D. Pa. 1971) (first one-and-one-half-month delay was reasonable; next three-and-one-halfmonth delay was unjustified); United States v. Godfrey, 243 F. Supp. 830 (D.D.C. 1965), aff $d, 358$ F.2d 850 (D.C. Cir. 1966) (first two-month delay was reasonable; next two-month delay was unjustifiable); Marks v. State, 496 P.2d 66 (Alas. 1972) (first one-month delay was reasonable; second seven-month delay was unjustified); of. United States v. Jackson, 504 F.2d 337 (8th Cir. 1974), cert. denied, 420 U.S. 964 (1975) (first six-month delay was reasonable; second five-month delay was unjustified, but court refused to dismiss indictment because defendant had not demonstrated actual prejudice). Contra, People v. Vanderburg, 32 Cal. App. 3d 526, 108 Cal. Rptr. 104 (1973) (court found the first nine-month delay reasonable, and the second eighteen-day delay after the agent had "broken cover" reasonable as well, due to the number of indictments being sent through the grand jury). 
that "the Due Process inquiry must consider the reasons for the delay as well as the prejudice to the accused." 97 Thus, under a constitutional analysis the government's justification must be considered regardless of the degree of prejudice suffered by the accused. On the other hand, a supervisory powers approach would afford the courts more flexibility in passing upon the claim of an accused and would permit the courts to ignore the government's justification in cases of extreme prejudice.

\section{Risk of Erroneous Conviction.}

The Ross court pointed out that one of the reasons for its decision was that the state's case against the defendant consisted "of the recollection of one witness refreshed by a notebook."'98 Although that factor was coupled with the defendant's plausible claim of inability to remember, the same court that decided Ross stated one year later:

Our discussion of prejudice in Ross and the subsequent Narcotics Delay cases was framed primarily in terms of the ability of the accused to prepare and present a defense at trial. But the ultimate prejudice that has concerned us in these cases has been the risk of erroneous conviction attributable to the process which led to the verdict of guilt. Delays prior to arrest which hinder or prevent presentation of a defense shackle our system of determining truth through the adversary process. The reliability of the verdict then depends solely upon the quality of the police identification. The more inherently unreliable the method of identification, the more the ultimate prejudice-the risk of erroneous conviction. ${ }^{99}$

Several courts have considered the reliability of the method of identification in evaluating pre-arrest delay due process claims. ${ }^{100}$ Some of the factors considered are whether the arresting officer was acquainted with or had seen the defendant prior to the arrest; ${ }^{101}$ the number of confrontations that took place between the arresting officer

97. United States v. Lovasco, 431 U.S. 783, 790 (1977).

98. Ross v. United States, 349 F.2d 210, 215 (D.C. Cir. 1965).

99. Woody v. United States, 370 F.2d 214, 216 (D.C. Cir. 1966).

100. See cases cited at notes 101-06 infra. See generally United States v. Jones, 524 F.2d 834 (D.C. Cir. 1975).

101. See, e.g., United States v. Mills, 463 F.2d 291 (D.C. Cir. 1972) (officer had seen defendant several times before arrest and knew defendant by nickname); King v. United States, 369 F.2d 213 (D.C. Cir. 1966), cert. denied, 387 U.S. 910 (1967) (officer had known defendant for six to eight years); People v. Vanderburg, 32 Cal. App. 3d 526, 108 Cal. Rptr. 104 (1973) (officer knew defendant before sale of narcotics); State v. Gardner, 534 S.W.2d 284 (Mo. 1976) (agent knew defendant from high school and grade school); State v. Hackett, 26 N.C. App. 239, 215 S.E.2d 832, cert. denied, 288 N.C. 246, 217 S.E.2d 670 (1975) (agent had known defendant for two years); State v. McClintick, 23 Ohio Misc. 194, 255 N.E.2d 885 (1970) (officer saw and knew defendant before and after sales); Commonwealth v. McCloud, $218 \mathrm{~Pa}$. Super. Ct. 230, 275 A.2d 841 (1971) (one informant had known defendant for over thirty years). 
and the defendant; ${ }^{102}$ the length of those confrontations; ${ }^{103}$ the adequacy of the officer's notes, if used in the process of identifying the defendant; ${ }^{104}$ whether the officer relied solely on his notes to identify the defendant, or had some independent recollection; ${ }^{105}$ and whether there was sufficient corroboration of the arresting officer's testimony. ${ }^{106}$

Consideration of these factors may be improper under a constitutional analysis, for it is questionable whether external evidence of the

102. See, e.g., United States v. Cowsen, 530 F.2d 734 (7th Cir.), cert. denied, 426 U.S. 906 (1976) (three encounters); Robinson v. United States, 459 F.2d 847 (D.C. Cir. 1972) (four purchases); United States v. Golden, 436 F.2d 941 (8th Cir.), cert. denied, 404 U.S. 910 (1971) (two purchases); Jordan v. United States, 416 F.2d 338 (9th Cir. 1969), cert. denied, 397 U.S. 920 (1970) (two purchases); McKay v. State, 489 P.2d 145 (Alas. 1971) (three purchases); In re W.C.R., III, 297 A.2d 335 (D.C. 1972) (multiple contacts); People v. M., 61 Misc. 2d 542, 306 N.Y.S.2d 38 (County Ct. 1969) (repeated sales); State v. McClintick, 23 Ohio Misc. 194, 255 N.E.2d 885 (1970) (several sales); Commonwealth v. De Rose, 225 Pa. Super. Ct. 8, 307 A.2d 425 (1973) (one isolated event).

103. See, e.g., United States v. Mills, 463 F.2d 291 (D.C. Cir. 1972) (dim lighting, one brief encounter); Robinson v. United States, 459 F.2d 847 (D.C. Cir. 1972) (much time spent with defendant); Bey v. United States, 350 F.2d 467 (D.C. Cir. 1965) (lengthy, closely spaced confrontations).

104. See United States v. Jones, 524 F.2d 834 (D.C. Cir. 1975) (officer had detailed notes and description); United States v. Mills, 463 F.2d 291 (D.C. Cir. 1972) (officer had good notes with name and description of defendant on drug envelopes); People v. Vanderburg, 32 Cal. App. 3d 526, 108 Cal. Rptr. 104 (1973) (officer had good notes).

105. Some courts have noted that the officer did not use any notes to testify. United States v. Bray, 442 F.2d 1064 (9th Cir. 1971); United States v. Golden, 436 F.2d 941 (8th Cir.), cert. denied, 404 U.S. 910 (1971); United States v. Morris, 308 F. Supp. 1348 (E.D. Pa. 1970). Other courts have noted that the officer used his notes sparingly, to refresh his recall as to details or collateral matters. United States v. Baker, 424 F.2d 968 (4th Cir. 1970); United States v. Sanchez, 361 F.2d 824 (2d Cir. 1960); Bey v. United States, 350 F.2d 467 (D.C. Cir. 1965); McKay v. State, 489 P.2d 145 (Alas. 1971); State v. Gardner, 534 S.W.2d 284 (Mo. 1976); State v. McClintick, 23 Ohio Misc. 194, 255 N.E.2d 885 (1970). Other courts have noted that the officer had no independent recollection and relied entirely upon his notes. Jackson v. United States, 351 F.2d 821 (D.C. Cir. 1965).

106. Several courts have noted that there was sufficient corroboration of the officer's testimony. United States v. Cowsen, 530 F.2d 734 (7th Cir.), cert. denied, 426 U.S. 906 (1976) (corroboration by another agent); United States v. Golden, 436 F.2d 941 (8th Cir.), cert. denied, 404 U.S. 910 (1971) (corroboration by other agents); United States v. Baker, 424 F.2d 968 (4th Cir. 1970) (corroboration by co-defendant); Wilson v. United States, 409 F.2d 184 (9th Cir.), cert. denied, 395 U.S. 983 (1969) (corroboration by two witnesses); United States v. Stewart, 426 F. Supp. 58 (E.D. Mich. 1976) (corroboration by several witnesses and a purported accomplice); Commonwealth v. McCloud, $218 \mathrm{~Pa}$. Super. Ct. 230, 275 A.2d 841 (1971) (corroboration by several witnesses, two agents and one informant); $c$. United States v. Baillie, 316 F. Supp. 892 (D. Hawaii 1970) (court stated that although there was sufficient corroboration, such corroboration is not demanded). A few courts have dismissed indictments and reversed convictions, noting a lack of corroboration. Woody v. United States, 370 F.2d 214 (D.C. Cir. 1966) (defendant was convicted solely on the basis of the uncorroborated testimony of the undercover officer); United States v. Jones, 322 F. Supp. 1110 (E.D. Pa. 1971) (accompanying agents were not close enough to observe any more than that defendant went to the car, so acting agent's testimony was uncorroborated); People v. Hernandez, 15 Mich. App. 141, 170 N.W.2d 851 (1969) (defendant was convicted on uncorroborated testimony); Commonwealth v. De Rose, 225 Pa. Super. Ct. 8, 307 A.2d 425 (1973) (uncorroborated identification by one witness to one isolated event). 
defendant's guilt is relevant to a due process claim. ${ }^{107}$ Under the Ross supervisory powers analysis, however, it would be completely logical to consider the quality of the state's evidence.

\section{Standards For Evaluation}

In evaluating pre-arrest delay claims, the factors discussed above have been weighted differently by various courts. It is important to analyze the approaches that have been taken, because the weight attached to each factor, the peculiar manner in which the factors are woven into some general standard and the allocation of the burden of proof on the various issues may significantly affect the defendant's success in obtaining a dismissal. It should be remembered throughout the following discussion that there are variations within each general category, depending upon the degree of prejudice required by the court.

\section{A. The Defendant Must Show Prejudice and That the Delay Was a Deliberate Tactical Device.}

Placing the burden on the accused to show that the pre-arrest delay was an intentional device employed by the prosecution to gain

107. Cf. Mapp v. Ohio, 367 U.S. 643 (1961); Weeks v. United States, 232 U.S. 383 (1914) (both cases holding that the fourth amendment mandates suppression of illegally seized evidence regardless of the fact that the evidence clearly establishes guilt). The Supreme Court also refused to consider the evidence against the defendant in evaluating his fourteenth amendment due process claim in Rochin v. California, 342 U.S. 165 (1952). The Rochin Court noted that even completely reliable evidence should not be admissible if it would "offend the community's sense of fair play and decency." Id. at 173. It is at least arguable that if a defendant has suffered "actual prejudice" due to a state-induced pre-arrest delay, it would offend society's notions of "fair play" to permit consideration of the state's evidence to which the defendant cannot adequately respond. Finally, in the recent case of Brewer v. Williams, 430 U.S. 387 (1977), the Supreme Court suppressed the defendant's incriminating statements and testimony that led the arresting officers to the dead body of a small child, finding that the defendant's sixth amendment right to counsel had been violated. The Court did not dispute the lower court's finding that there was overwhelming evidence against the defendant and that there was no doubt as to the defendant's guilt, but the Court did not find this relevant to its determination as to whether a constitutional violation had occurred:

The crime of which Williams was convicted was senseless and brutal, calling for swift and energetic action by the police to apprehend the perpetrator and gather evidence with which he could be convicted. No mission of law enforcement officials is more important. . . . Although we do not lightly affirm the issuance of a writ of habeas corpus in this case, so clear a violation of the Sixth and Fourteenth Amendments as here occurred cannot be condoned. The pressures on state executive and judicial officers charged with the administration of the criminal law are great, especially when the crime is murder and the victim a small child. But it is precisely the predictability of those pressures that makes imperative a resolute loyalty to the guarantees that the Constitution extends to us all.

Id. at 406 . If, as the Marion-Lovasco cases indicate, the Constitution extends fifth amendment protection to defendants who are substantially prejudiced by state-induced pre-arrest delay, then, as in Brewer, evidence of the defendant's guilt is not a proper factor for consideration in evaluating the alleged constitutional violation. 
some tactical advantage over the defendant and that the delay was prejudicial makes it almost impossible for the accused to obtain a dismissal of the indictment. All of the courts that espouse this standard demand a showing of substantial actual prejudice and some form of malicious intent on the part of the prosecution. ${ }^{108}$ While it is difficult enough for a defendant who has no recall of events surrounding the crime to make a showing of actual prejudice, it is even more difficult for a defendant to establish a state of mind or motivation that is peculiarly within the knowledge of the prosecution. Thus, it is not surprising that of the six courts that follow this approach, only one has reversed a conviction on pre-arrest delay grounds-and that decision was predicated on an extreme factual situation. ${ }^{109}$

In support of this standard, it should be noted that its substantive requirements and allocation of the burdens of proof are in literal compliance with the constitutional test set forth in the Marion dictum. ${ }^{110}$ However, supplemental treatment of the claim under a supervisory powers review would help mitigate the problems this rigorous standard presents for an innocent defendant.

\section{B. The Defendant Must Show Prejudice and That There Was No Reason for the Delay.}

There are two states whose courts hold that both the absence of a valid reason for the delay and the fact of prejudice must be established in order to support a due process claim. ${ }^{111}$ The conjunctive nature of these requirements and the absolutism of the first element make the standard almost as harsh as the one just discussed, although the defendant can succeed merely by showing a lack of justification for the delay and is not required to prove malicious intent on the part of the state. The harshest feature of this standard is the allocation of the bur-

108. Crawford v. State, 6 Ala. App. 71, 342 So. 2d 450 (1977); State v. Wilbanks, 95 Idaho 346, 509 P.2d 331 (1973); State v. Royal, 217 Kan. 197, 535 P.2d 413 (1975); Blake v. State, 15 Md. App. 674, 292 A.2d 780 (1972); People v. Johnson, 41 Mich. App. 34, 199 N.W.2d 561 (1972); People v. Collins, 66 Misc. 2d 340, 320 N.Y.S.2d 693 (County Ct. 1971).

109. People v. Hernandez, 15 Mich. App. 141, 170 N.W.2d 851 (1969). In Hernandez the court noted that there was no justification for the delay; that marked money was allegedly used but never recovered; that the defendant was uneducated and illiterate; that there was a question of credibility of the witness as a result of a deal between the witness and the prosecutor; that there was otherwise no corroboration; that the defendant denied all knowledge of the transaction; and that the arrest of the defendant was marked by unnecessary severity and indignity. That same court subsequently reversed the quashing of an indictment, People v. Iaconis, 31 Mich. App. 703, 188 N.W.2d 175 (1971), and affirmed a conviction obtained after an unsuccessful pre-arrest delay claim, People v. Johnson, 41 Mich. App. 34, 199 N.W.2d 561 (1972).

110. See text accompanying note 25 supra.

111. Marks v. State, 496 P.2d 66 (Alas. 1972); State v. Roundtree, 106 N.J. Super. 135, 254 A.2d 337 (1969), rev'd on other grounds, 118 N.J. Super. 22, 285 A.2d 564 (1971). 
dens - the defendant ultimately has the burden of persuasion on both issues, although the state must offer some evidence of justification once the defendant establishes sufficient prejudice. ${ }^{112}$ Thus, assuming that the defendant demonstrates actual prejudice and the state contends that further investigation was necessary, or that the defendant's identity was unknown, or offers some other justification, the burden rests on the defendant to disprove these allegations, although the information upon which they are based may lie peculiarly within the knowledge of the prosecution. It would seem more logical to place the burden of persuasion concerning the issue of justification on the party with access to all of the relevant information.

Thus, the relief this standard provides from the Marion test is not very substantial, because in practice the defendant will probably not succeed in a motion for dismissal unless the state concedes a lack of justification. ${ }^{13}$ As noted above, a supplemental supervisory powers analysis would tend to mitigate this problem.

\section{Weighing the State's Justification for the Delay Against the Prejudice to the Defendant.}

Several courts apply a balancing test to determine whether the state's justification for pre-arrest delay outweighs any prejudice resulting to the defendant. ${ }^{114}$ This standard, which is a clear departure from the Marion test and from that discussed immediately above, allows the courts to consider the reasonableness of the justification advanced by the prosecution. ${ }^{115}$ Thus, the defendant's motion for dismissal is not foreclosed merely by a finding that some cause for delay actually existed. Furthermore, the burdens of persuasion are more logically placed: the defendant has the burden to demonstrate prejudice, but the

112. State v. Roundtree, 118 N.J. Super. 22, 285 A.2d 564 (1971).

113. See Marks v. State, 496 P.2d 66 (Alas. 1972) (reversing a conviction where the state had not even attempted to justify the pre-arrest delay).

114. Second Circuit, Sixth Circuit, Eighth Circuit, District Court for Maryland, District Court for the Eastern District of Michigan, New Mexico Supreme Court and Wisconsin Supreme Court. See cases cited at notes 117-18 infra.

115. See United States v. Jackson, 504 F.2d 337 (8th Cir. 1974), cert. denied, 420 U.S. 964 (1975): "Even the legitimate excuse of a continuing undercover investigation may be stretched to the breaking point; at some point, the accused's right to due process of law must prevail." 504 F.2d at 340; accord, United States v. Alderman, 423 F. Supp. 847 (D. Md. 1976) where, although the delay was not malicious and was probably due to higher priority being given to other investigations, the court stated: "If the reason for such delay is the scarcity of prosecutors and the abundance of culpable public officials, the answer is found not in shortchanging the due process rights of individuals but rather in adequately funding and staffing prosecutorial offices." Id. at 857 . For factors considered in evaluating the reasonableness of delay due to an undercover narcotics investigation, see text accompanying notes 89-96 supra, note 94 supra and cases cited at note 96 supra. 
prosecution has the burden to prove a valid and important reason for the delay. ${ }^{116}$ It should be noted, however, that the courts following this standard demand a strong showing of actual prejudice, ${ }^{117}$ and that if sufficient prejudice is not demonstrated, the indictment will be upheld even if the delay is without justification. ${ }^{118}$ Indeed, the majority of the federal cases decided under this standard have been disposed of by a finding that sufficient prejudice had not been demonstrated, and although the courts have usually made mention of the government's justification, they have not found it actually necessary to employ a balancing process. ${ }^{119}$ The federal courts that have found sufficient prejudice to necessitate application of the balancing test have tended to dismiss the indictments, giving little weight to the government's justification. ${ }^{120}$ The state courts, however, typically go through the process of balancing even when the resulting prejudice has not been substantial. $^{121}$

Aside from the difficulties associated with demonstrating the high degree of prejudice required by this approach, ${ }^{122}$ it is clear that even a reasonable justification does not reduce the amount of prejudice suffered by the defendant. ${ }^{123}$ This second concern is somewhat mitigated by the fact that, excluding undercover narcotics investigations, the courts have been reluctant to find that the justification offered by the prosecution for the delay outweighs the prejudice established by the defendant. ${ }^{124}$ Nevertheless, the first factor remains a rigid obstacle to the success of a defendant's motion for dismissal, and, once again, a supplementary supervisory powers analysis would seem to be appropriate.

A variation of the balancing approach is found in several jurisdic-

116. See United States v. Stewart, 426 F. Supp. 58 (E.D. Mich. 1976).

117. See, e.g., id.; United States v. Alred, 513 F.2d 330 (6th Cir.), cert. denied, 423 U.S. 828 (1975); United States v. Iannelli, 461 F.2d 483 (2d Cir.), cert. denied, 409 U.S. 980 (1972); United States v. Stewart, 426 F. Supp. 58 (E.D. Mich. 1976); United States v. Alderman, 423 F. Supp. 847 (D. Md. 1976); State v. Baca, 82 N.M. 144, 477 P.2d 320 (1970); Gonzales v. State, 47 Wis. 2d 548, 177 N.W.2d 843 (1970).

118. See United States v. Jackson, 504 F.2d 337 (8th Cir. 1974), cert. denied, 420 U.S. 964 (1975).

119. See id; United States v. Capaldo, 402 F.2d 821 (2d Cir. 1968), cert. denied, 394 U.S. 989 (1969); United States v. Stewart, 426 F. Supp. 58 (E.D. Mich. 1976).

120. See United States v. Alderman, 423 F. Supp. 847 (D. Md. 1976); United States v. Haulman, 288 F. Supp. 775 (E.D. Mich. 1968).

121. See State v. Baca, 82 N.M. 144, 477 P.2d 320 (1970); Gonzales v. State, 47 Wis. 2d 548, 177 N.W.2d 843 (1970).

122. See text following note 71 supra.

123. See text following note 96 supra.

124. See cases cited at note 120 supra. 
tions ${ }^{125}$ that require dismissal of the indictment, even absent a showing of prejudice, if the delay is motivated by a desire to gain a tactical advantage over the defendant. ${ }^{26}$ The value of this standard depends upon the purpose to be served by a defendant's fifth amendment objection. If the function of dismissing indictments on the basis of pre-arrest delay is to deter the police and prosecution from engaging in such conduct, then the standard is clearly logical. However, if the function of such dismissals is to protect the defendant's right to a fair trial, then a dismissal without a showing of prejudice is an inappropriate remedy. This is not to say that both of these functions-deterrence and due process-cannot be mutually served. In fact, application of this standard is actually nothing more than an application of the Marion test in disjunctive form.

\section{After Prejudice and Justification Have Been Shown, the Court will Consider the Reliability of the Method of Identification.}

It should be noted that none of the standards discussed to this point have taken into consideration the reliability of the method of identification, which is a key factor in determining the risk of an erroneous conviction. Several courts do consider this factor, but only after both prejudice and justification have been shown. ${ }^{127}$ The burdens under this standard seem to be properly placed: the defendant has the burden of establishing prejudice, the state has the burden of establishing justification and the court has the responsibility of inquiring into the strength of the state's case as it relates to the risk of an erroneous conviction. ${ }^{28}$

The standard itself, however, is of questionable validity. If the right upon which a pre-arrest delay claim is based is of constitutional dimension, evidence of the defendant's guilt may not be a proper factor for consideration. ${ }^{129}$ But if the courts were passing upon such claims under their supervisory powers, it would be logical to consider the quality of the state's evidence, and the courts would have more flex-

125. United States v. Mays, 549 F.2d 670 (9th Cir. 1977); United States v. Stamas, 443 F.2d 860 (1st Cir.), cert. denied, 404 U.S. 851 (1971); Hamilton v. Lumpkin, 389 F. Supp. 1069 (E.D. Va. 1975).

126. See United States v. Stamas, 443 F.2d 860 (1st Cir.), cert. denied, 404 U.S. 851 (1971); State v. Dietz, 289 N.C. 488, 223 S.E.2d 357 (1976).

127. People v. Vanderburg, 32 Cal. App. 3d 526, 108 Cal. Rptr. 104 (1973); People v. Lawson, 38 Ill. App. 3d 239, 347 N.E.2d 430 (1976), rev'd on other grounds, 67 Ill. 2d 449, 367 N.E.2d 1244 (1977); see State v. Bryson, 53 Haw. 652, 500 P.2d 1171 (1972).

128. See People v. Vanderburg, 32 Cal. App. 3d 526, 108 Cal. Rptr. 104 (1973); People v. Lawson, 38 Ill. App. 3d 239, 347 N.E.2d 430 (1976), rev'd on other grounds, 67 Ill.2d 449, 367 N.E.2d 1244 (1977).

129. See note 107 supra. 
ibility in protecting defendants from the risk of erroneous convictions, which was the primary focus of Ross. ${ }^{130}$

\section{E. Weighing Justification Against Both Prejudice and the Reliability of the Method of Identification.}

Several courts have noted that the resulting harm to the defendant in a pre-arrest delay case may include prejudice or an unreliable method of identification, or both. ${ }^{131}$ The Court of Appeals for the District of Columbia considered the "lurking danger of misidentification" to be an element of prejudice, ${ }^{132}$ whereas the other six courts that embrace this standard view the method of identification as an independent factor, weighing it along with the defendant's allegation of prejudice against the reasons asserted for the delay. ${ }^{133}$ Thus, under this standard, the state's evidence of the defendant's guilt is automatically considered in the adjudication of a pre-arrest delay claim, while under the standard just discussed, such evidence is considered only after both prejudice and justification have been shown.

This standard most directly serves the Ross objective of minimizing the risk of conviction of an innocent man. It also lends itself to a flexible evaluation of prejudice, in that a minimal showing of prejudice, such as a general inability to recall, may be deemed substantial in light of the unreliability of the state's evidence. Thus, a defendant's prearrest delay claim would not necessarily be foreclosed by his inability to demonstrate, with particularity, "actual prejudice." The only problem with this standard, as noted in the preceding section, is that to the extent that a motion for dismissal due to pre-arrest delay is based upon constitutional grounds, evidence of the defendant's guilt is not an appropriate factor for consideration. However, this approach would seem to be the most logical and flexible scheme under a supervisory powers analysis; indeed, it encompasses the very three factors that were considered determinative in Ross. ${ }^{134}$

130. See text accompanying note 99 supra.

131. See cases cited at notes $132-33$ infra.

132. United States v. Jones, 524 F.2d 834, 841 (D.C. Cir. 1975); accord, Robinson v. United States, 459 F.2d 847, 853 (D.C. Cir. 1972).

133. United States v. Morris, 308 F. Supp. 1348 (E.D. Pa. 1970); United States v. Peterson, 302 F. Supp. 1232 (D. Minn. 1969); In re G.T., 304 A.2d 865 (D.C. 1973); State v. Thomas, 529 S.W.2d 379 (Mo. 1975); State v. McClintick, 23 Ohio Misc. 194, 255 N.E.2d 885 (1970) (better identification requires greater showing of prejudice); Commonwealth v. McCloud, $218 \mathrm{~Pa}$. Super. Ct. 230, 275 A.2d 841 (1971).

134. See text accompanying notes 11-15 supra. 


\section{A Two-Pronged Analysis of Pre-Arrest Delay Claims: THE "Right" AND THE "PRINCIPLE"}

For the past twelve years, federal and state courts have been applying the above conflicting standards in an attempt to deal with claims of pre-arrest delay solely on a constitutional level. Some of the standards are impossible to meet except under the most extreme circumstances, while others appear more just but include consideration of factors posing legal and policy problems. Perhaps the basis of all of this confusion is the courts' misunderstanding of the purpose of a Rosstype claim, as distinguished from a more severe pre-arrest delay situation.

Pre-arrest delay problems can be divided into two categories. In the first category, the defendant has been denied due process of law because he is unable to prepare an adequate defense; in the second, the circumstances are such that trial of the defendant would lead to the risk of an erroneous conviction. The first category, which covers only the most extreme situations, clearly calls for a constitutional analysis, while the second category, which relates to Ross-type claims, should be handied under the courts' supervisory responsibilities over criminal proceedings. ${ }^{135}$ Once it is realized that the Ross situation creates a different problem, for which remedies independent of constitutional considerations exist in the federal courts and in most state courts, the development and application of standards for pre-arrest delay claims should be relatively uncomplicated.

\section{A. The "Right": Where the Defendant Has Been Denied Due Process.}

In Marion the Supreme Court stated that a defendant's fifth amendment rights would be violated if it were shown at trial that the pre-arrest delay had caused substantial prejudice to his right to a fair trial and that the delay was an intentional device to gain a tactical advantage over him. Although the Marion test was merely dictum, it would not seem improper to suggest that it be adopted, but applied in a disjunctive fashion. Disjunctive application would serve the goals of insuring due process to criminal defendants and of deterrence of improper law enforcement behavior. Even if both parts of the Marion test are subject to rigid standards of proof, neither would be impossible to demonstrate independently; ${ }^{136}$ however, if the test were applied con-

135. See authorities cited at note 20 supra.

136. For situations in which the defendant has succeeded in demonstrating sufficient actual prejudice, see text accompanying notes 68-71 supra and cases cited at note 68 supra. For situa- 
junctively, few, if any, defendants would succeed in their constitutional claims. ${ }^{137}$

Under the disjunctive approach, prosecutors and police who deliberately delay arrests or indictments simply would not be allowed to initiate a criminal action after an unreasonable period of time. The result of this approach is not unlike the suppression of illegally obtained evidence ${ }^{138}$ or confessions ${ }^{139}$ to deter improper action by law enforcement authorities. The potential that such improper action-be it unlawfully seizing evidence, illegally obtaining confessions or deliberately delaying arrests - has for denying constitutional rights justifies severe sanctions for the purpose of deterrence.

The existence of substantial prejudice is an independent constitutional concern. If a defendant can show that because of the delay he is unable to locate specifically identified witnesses or documents, or that material witnesses have died or evidence has been destroyed, then he should not be forced to stand trial. In order to assure that the claimed prejudice is not being feigned or exaggerated, the defendant would have the burden of proving that he made diligent attempts to locate the witnesses or the documents, or to find substitute witnesses or evidence. If this burden is met, then the state's justification for the delay should not even be considered. ${ }^{140}$ Balancing those factors would not decrease the amount of prejudice suffered by the accused, and if he has demonstrated the substantial prejudice described above, he has been denied due process of law because of his inability to prepare an adequate defense.

Although the level of prejudice required would be difficult to prove and the standard as a whole remains subject to the inequities discussed earlier, ${ }^{141}$ disjunctive application of the Marion test -would assure the defendant the minimal protections necessary to guarantee a fair trial, and that is all that the Constitution requires. Furthermore, these inequities would be substantially ameliorated by the application of a supplementary supervisory powers scheme of review, discussed below, which would have the requisite flexibility to deal with less extreme Ross-type pre-arrest delay claims.

tions in which the defendant has shown some sort of tactical advantage on the part of the state, see text accompanying notes 81-83 \& 92 supra and cases cited at note 96 supra.

137. For a list of cases in which the court applied the test conjunctively, see note 108 supra.

138. See Mapp v. Ohio, 367 U.S. 643 (1961); Weeks v. United States, 232 U.S. 383 (1914).

139. See Miranda v. Arizona, 384 U.S. 436 (1966).

140. But see text accompanying notes 42 \& 97 supra.

141. See text following note 71 supra and accompanying note 72 supra. 
B. The "Principle": Where the Defendant is Subject to the Risk of an Erroneous Conviction.

In cases in which the defendant cannot prove a deliberate tactical delay or cannot establish prejudice with sufficient particularity to satisfy the disjunctive Marion standard, he should be able to assert his pre-arrest delay claim under a set of equitable principles adopted and applied by the courts through their supervisory responsibilities over criminal proceedings. It should be recalled that the Ross court's major concern was that the defendant not be made to stand trial under circumstances that would lead to the risk of an erroneous conviction. The equitable standard would involve weighing the state's justification against the resulting harm to the defendant, which includes both prejudice in preparing his defense and the risk of erroneous conviction arising from unreliability in the method of identification.

The resulting prejudice and the method of identification should be considered in the conjunctive, so that a minimal showing of prejudice (a general inability to recall) would be afforded substantial weight if the identification procedure were highly unreliable. On the other hand, if the defendant asserts a general inability to recall in the face of a highly reliable method of identification, then the resulting harm would not be found substantial. Under this approach, it would be proper to consider evidence of the defendant's guilt, as the court would not be balancing away a constitutional "right," 142 but rather would be applying "principles" of equity to evaluate the risk of an erroneous conviction. ${ }^{143}$ Furthermore, it would not be improper to balance the resulting harm to the defendant against the state's justification for the delay, as the courts' supervisory powers necessarily include the furtherance of effective law enforcement as well as protection of the defendant. Thus, all of the factors that create problems when examined from a constitutional viewpoint could be validly and logically considered under a court's supervisory powers.

The gist of the Ross "principle" is that the courts could evaluate these factors in an extremely flexible manner, the end being to guarantee "fundamental fairness" both to the defendant and to the state. The requirement of prejudice would not be an insurmountable barrier to a defendant if the method of identification were so unreliable as to engender the risk of an erroneous conviction. Furthermore, the consideration of justification would permit delays necessary for effective

142. See the Supreme Court's analysis in Brewer v. Williams, 430 U.S. 387 (1977), discussed at note 107 supra.

143. See text accompanying note 19 supra and cases cited therein. 
law enforcement and the propriety of delays caused by negligence or lack of manpower would be determined in light of the resulting harm to the defendant. In short, under its supervisory powers the court could consider and weigh all of the above factors and determine whether trial of the defendant might lead to an erroneous conviction. The "principle" would be one of "fundamental fairness."

\section{CONCLUSION}

The problem of pre-arrest delays, dealt with in Ross under the court's supervisory responsibilities and discussed by the Supreme Court in dicta in Marion and Lovasco as a potential constitutional violation, has been handled in a conflicting manner by the courts over the past twelve years. The current state of the law. makes imperative further clarification by the Supreme Court in order to avoid the inequitable administration of justice. It is suggested that, for extreme cases, the Marion standard be conclusively adopted in a disjunctive fashion, so that constitutional guarantees of due process of law would mandate dismissal if the delay were perpetrated by the state to gain a tactical advantage over the accused, or if the accused demonstrated that he had suffered actual, substantial and irremediable prejudice. It is further suggested that the lower federal and state courts, on their own initiative, exercise their supervisory powers over criminal proceedings to dismiss indictments obtained under circumstances, such as those in Ross, that tend to lead to the risk of an erroneous conviction. 